\title{
Effects of alternative conifer release treatments on terrestrial gastropods in northwestern Ontario
}

\author{
by J.W. Hawkins ${ }^{1}$, M.W. Lankester ${ }^{1}$, R.A. Lautenschlager ${ }^{2}$ and F.W. Bell ${ }^{2}$
}

Changes in terrestrial gastropod species richness and density in regenerating spruce plantations following application of four conifer release treatments including two chemical herbicides (Vision ${ }^{\otimes}$ [a.i. glyphosate] and Release ${ }^{\circledR}$ [a.i. triclopyr]), cutting by mechanical means (Silvana Selective/Ford Versatile), and motormanual cutting with brush saws are discussed. Mean gastropod density increased to a maximum of $21 \mathrm{~m}^{-2}$ over the summer of 1993 (pre-treatment) when a total of 27,396 gastropods were collected but remained fairly stable at about $10 \mathrm{~m}^{-2}$ throughout the summer of 1994 (post-treatment) when only 20,199 were collected. This difference between years was not related to the conifer release treatments, since gastropod densities on both treated and control areas were lower in 1994. The decline in 1994 was probably due to decreased population size and detectability because of less rainfall. The lack of difference following treatments was attributed to rapid re-establishment of the herbaceous layer which probably continued to provide favourable conditions for snails and slugs.

Gastropod density was higher in a nine-year-old regenerating spruce plantation $\left(15.5 \pm 1.3 \mathrm{~m}^{-2}\right)$ than in a 70 -year-old mixedwood forest $\left(9.4 \pm 0.6 \mathrm{~m}^{-2}\right)$ and species richness was also slightly greater ( $20 \mathrm{spp}$. vs. $18 \mathrm{spp}$.) in the plantation. These differences were attributed to the more abundant near-ground vegetation and the greater amount of deciduous litter characterizing the regenerating plantation.

Key words: clearcutting, terrestrial gastropods, snails, slugs, conifer release, Fallingsnow Ecosystem Project, herbicides, spruce plantations, vegetation
Cet article fait état des changements survenus au niveau de la variété et de la densité des espèces de gastropodes terrestres retrouvés dans des plantations d'épinette suite à la réalisation de quatre traitements de dégagement des conifères comprenant deux traitements par phytocides chimiques (Vision ${ }^{\circledR}$ [é.a. glyphosate] et Release ${ }^{\circledR}$ [é.a. triclopyr], un dégagement mécanique (Silvana Selective/Ford Versatile), et un débroussaillage manuel mécanisé effectué au moyen de scics débroussailleuses. La densité moyenne de gastropodes a augmenté pour atteindre un maximum de $21 \mathrm{~m}^{-2}$ au cours de l'été 1993 (pré-traitement) alors qu'un total de 27396 gastropodes furent recueillis, mais demeura sensiblement stable à près de $10 \mathrm{~m}^{-2}$ au cours de l'été 1994 (posttraitement) alors que seulement 20199 gastropodes furent recueillis. Cette différence entre les deux années n'a pas été reliée aux traitements de dégagement des coniferes, puisque les densités de gastropodes à la fois dans les parcelles traitées et les parcelles témoins avaient été plus faibles en 1994. Le déclin de 1994 provenait probablement d'une diminution de la taille de la population et de la possibilité de détecter les spécimens suite à une diminution des précipitations. Le fait qu'il n'y a pas de différence suite aux traitements a été attribué au rétablissement rapide de la couverture herbacée ce qui a permis de maintenir des conditions favorables pour les escargots et les limaces.

La densité des gastropodes était supérieure dans les plantation d'épinette de 9 ans $\left(15.5 \pm 1.3 \mathrm{~m}^{-2}\right)$ que dans les peuplements mélangés de 70 ans $\left(9.4 \pm 0.6 \mathrm{~m}^{-2}\right)$ et la variété des espèces était également légèrement supérieure (20 espèces vs 18 espèces) dans les plantations. Ces différences flurent attribuées à la présence d'une végétation près du sol et à une litière de feuillus plus abondantes par rapport aux plantations en voie de régénération.

Mots clés: coupe à blanc, gastropodes terrestres, escargots, limaces, dégagement des conifëres, projet écosystémique de Fallingsnow, phytocides, plantations d'épinette, végétation

\section{Introduction}

Competition from undesirable vegetation is a common problem in young conifer plantations. Competing hardwoods, shrubs and herbs limit the resources available to conifer seedlings, leading to a potential reduction in yield and a possible increase in rotation time between harvests (Sutton 1969; Radosevich and Osteryoung 1987; Freedman et al. 1993). To ameliorate the effects of undesirable vegetation, a variety of conifer release methods are practiced that reduce the density of competing vegetation, allowing young conifers to become established (Walstad and Kuch 1987).

The most common method of conifer release in re-forested areas is the aerial application of chemical herbicides (Campbell 1990; Lautenschlager 1993). Although herbicides

\footnotetext{
${ }^{1}$ Department of Biology, Lakehead University, 955 Oliver Road, Thunder Bay, Ontario, Canada P7B 5E1.

${ }^{2}$ Ontario Forest Research Institute, 1235 Queen Street East, P.O. Box 969, Sault Ste. Marie, Ontario, Canada P6A 5N5.
}

have proven effective and economical in the past (Campbell 1984), public concern over their environmental effects (Campbell 1990; Freedman 1991; Environics Research Group 1992; Buse et al. 1995) has prompted the search for alternative methods to control competing vegetation (Campbell 1991; Wagner 1993). Two alternatives to chemicals are mechanical and motor-manual release, although both methods have the disadvantage of promoting rapid regrowth through sprouting of freshly cut hardwoods and shrubs (Campbell 1984; Wagner 1993).

Terrestrial gastropods play an important role in the ecology of the forest floor. They provide food for a variety of soil arthropods (Newell 1971; Brandmayr and Brandmayr 1986; Digweed 1993), ground foraging birds (South 1980), and small mammals (Hamilton 1941; Whitaker 1966; Rudge 1968; Whitaker and Mumford 1972; Churchfield 1984). As well, they are important intermediate hosts for a number of helminth parasites affecting vertebrate wildlife (Lankester and Anderson 1968; Gleich et al. 1977; Rowley et al. 1987; Raskevitz et al. 1991). Snails and slugs also play a role in lit- 
ter decomposition and the nutrient cycle of the forest floor (Mason 1970; Richter 1979).

Snails and slugs are relatively immobile and, consequently, cannot easily escape areas that are subjected to disturbance (Strayer et al. 1986). Changes in density and diversity of terrestrial gastropods should, therefore, reflect the immediate impact of a natural or experimental disturbance on their habitat. Studies on the ability of snails and slugs to re-colonize a disturbed area have yielded conflicting results. Reinink (1979) found a positive correlation between species richness of gastropods and the age of forest plantations in the Netherlands. In addition, Cameron et al. (1980) reported more species of gastropods in British hedgerow habitat established prior to the 20 th century than in more recently established hedgerows. However, Strayer et al. (1986), in a study of 16 forested sites disturbed by a variety of events, including small-scale clearcutting, found no correlation between species diversity of gastropods and time elapsed since disturbance.

Terrestrial gastropod distributions are positively correlated with percent cover of vegetation (Boag and Wishart 1982), with the greatest abundances occurring in habitats dominated by deciduous tree and shrub growth (Gleich and Gilbert 1976; Beyer and Saari 1977; Kralka 1986). As well, snails and slugs depend on litter type (deciduous vs. coniferous) (Baker 1942; Burch 1956; Karlin 1961) and abundance (Locasciulli and Boag 1987). Alterations in near-ground vegetation cover, and the reduced accumulation of deciduous leaf litter associated with the removal of competing hardwood vegetation, could affect the density and diversity of gastropods inhabiting an area.

The primary objective of this study was to document changes in the richness and density of terrestrial gastropods following various alternative methods of managing competing vegetation on regenerating spruce plantations. Differences in gastropod species richness and abundance between a nineyear-old spruce plantation and a mature 70-year-old mixedwood forest were also examined.

\section{Methods}

\section{Study Area}

The study area was located in Fraleigh Township $\left(48^{\circ} 08^{\prime} \mathrm{N}\right.$, $89^{\circ} 47^{\prime} \mathrm{W}$ ), about $60 \mathrm{~km}$ southwest of Thunder Bay, Ontario, within the Great Lakes-St. Lawrence Forest Region (Rowe 1972). Within each of four replicate blocks, four experimental treatments and a control were randomly assigned. The blocks, ranging in size from 28 to $52 \mathrm{ha}$, were surveyed and a $60 \times 60 \mathrm{~m}$ grid pattern staked in an alpha-numeric coordinate system, oriented north-south and east-west.

The conifer release treatments included four replications of: two chemical herbicides (Vision ${ }^{\circledR 3}$ [a.i glyphosate] and Release $^{\circledR 4}$ [a.i. triclopyr]) applied aerially by helicopter (Bell 206); cutting the vegetation by mechanical means using the Silvana Selective/Ford Versatile; motor-manual cutting with brush saws (Stihl FS420 and Husquavarna Professional clearing saws); and controls (no treatment). Glyphosate and triclopyr were applied at $1.5 \mathrm{~kg}$ a.e. $\mathrm{ha}^{-1}$ and $1.9 \mathrm{~kg}$ a.e. $\mathrm{ha}^{-1}$, respectively, on 16 August 1993. The brush saw treatment was applied between 12 and 22 October 1993, and the Silvana

\footnotetext{
${ }^{3}$ Trademark of Monsanto.

${ }^{4}$ Trademark of DowElanco.
}

Selective/Ford Versatile treatment between 19 October and 5 November 1993. Additional information about the study area and treatments can be found in Bell et al. (1997a,b) Lautenschlager et al. (1997), Simpson et al. (1997) and Thompson et al. (1997) in this issue of The Forestry Chronicle.

\section{Gastropod Collection}

Terrestrial gastropods were collected using corrugated cardboard sheets. The 1993 field season was devoted to collecting baseline data on terrestrial gastropod populations before the treatments were applied. Post-treatment gastropod collections were made in 1994. In early June 1993, ten cardboard sheets, each $0.85 \mathrm{~m}^{2}$, were placed in a systematic-random fashion on the forest floor, approximately $10-30 \mathrm{~m}$ apart, along each of three transects (based on the alphanumeric grid system) in the treatment areas ( 30 sheets treatment $^{-1} \times 5$ treatment areas $\times 4$ blocks $=600$ sheets total). New cardboard sheets were used for post-treatment sampling beginning in May 1994.

Each block was sampled, for a period of one to three days, four times during the snow-free season in both 1993 and 1994. Gastropods located beneath and on top of each cardboard sheet were identified to species, counted, and removed. The sheets were then replaced $1 \mathrm{~m}$ from the previously sampled location and left in position for approximately 14 days before sampling again.

Gastropods were identified using Pilsbry (1939-1948), Oughton (1948), and Burch (1962). Those species too small to be identified in the field were preserved in glycerin alcohol and identified later under a dissecting microscope at $16 \times$ magnification. Voucher specimens were sent to the Royal Ontario Museum, Toronto, where identifications were confirmed.

\section{Regenerating Plantation vs. Uncut Forest}

To determine if terrestrial gastropod species composition and abundance varied between a regenerating plantation and an uncut forest typical of the area, a fifth sampling site (three transects, each with 10 cardboard sheets) was established in 1994 in a 70-year-old forest adjacent to block three. The site had a tree layer dominated by white spruce (Picea glauca [Moench] Voss) and trembling aspen (Populus tremuloides Michx.) forming a closed canopy. The shrub layer was sparse and the herb layer dominated by large-leaf aster (Aster macrophyllus L.) and bunchberry (Cornus canadensis L.).

Gastropod species composition and abundance from the uncut forest were compared with those of the untreated control area on block three. Both areas were sampled for gastropods, within two to three days of each other, on five occasions (20 May, 29 June, 12 July, 25 July, 28 August 1994).

\section{Climatic Conditions}

Mean daily air temperatures and total monthly precipitation were obtained for April through September in 1993 and 1994 from the Thunder Bay station of the Atmospheric Environment Service, Environment Canada (approximately $50 \mathrm{~km}$ northeast of the study area).

\section{Statistical Analysis}

Differences among terrestrial gastropod densities were tested using only those species whose numbers exceeded $2 \%$ of the total collected. In all tests, the maximum probability 
Table 1. Total numbers of terrestrial gastropods collected from each of the four experimental blocks in the summers of 1993 (pre-treatment) and 1994 (post-treatment)

\begin{tabular}{|c|c|c|c|c|c|c|c|c|c|c|}
\hline & \multicolumn{4}{|c|}{1993} & \multirow[b]{3}{*}{ Total } & \multicolumn{4}{|c|}{1994} & \multirow[b]{3}{*}{ Total } \\
\hline & \multicolumn{4}{|c|}{ Block } & & \multicolumn{4}{|c|}{ Block } & \\
\hline & 1 & 2 & 3 & 4 & & 1 & 2 & 3 & 4 & \\
\hline Zonitoides arboreus & 3933 & 1688 & 1759 & 447 & 7827 & 2124 & 1050 & 1802 & 516 & 5492 \\
\hline Deroceras laeve & 607 & 1302 & 2257 & 951 & 5117 & 322 & 914 & 1284 & 672 & 3192 \\
\hline Discus cronkhitei & 1502 & 868 & 180 & 337 & 2887 & 800 & 420 & 326 & 119 & 1665 \\
\hline Euconulus fulvus & 643 & 507 & 1027 & 275 & 2452 & 354 & 906 & 963 & 284 & 2507 \\
\hline Strobilops labyrinthica & 304 & 265 & 791 & 523 & 1883 & 367 & 427 & 568 & 306 & 1668 \\
\hline Vitrina limpida & 253 & 263 & 1110 & 155 & 1781 & 62 & 135 & 291 & 45 & 533 \\
\hline Vertigo gouldi & 152 & 197 & 363 & 346 & 1058 & 218 & 214 & 396 & 252 & 1080 \\
\hline Striatura milium & 68 & 75 & 419 & 478 & 1040 & 77 & 81 & 85 & 251 & 494 \\
\hline Succinea ovalis & 62 & 155 & 345 & 355 & 917 & 67 & 136 & 370 & 214 & 787 \\
\hline Columella edentula & 89 & 127 & 217 & 174 & 607 & 347 & 301 & 219 & 144 & 1011 \\
\hline Anguispira alternata & 27 & 57 & 317 & 151 & 552 & 9 & 40 & 217 & 177 & 443 \\
\hline Cochlicopa lubrica & 84 & 18 & 173 & 17 & 292 & 73 & 36 & 171 & 9 & 289 \\
\hline Pallifera dorsalis & 20 & 19 & 121 & 46 & 206 & 5 & 15 & 41 & 17 & 78 \\
\hline Zöogenetes harpa & 13 & 16 & 91 & 78 & 198 & 9 & 36 & 46 & 37 & 128 \\
\hline Vertigo ovata & 38 & 40 & 59 & 61 & 198 & 39 & 47 & 70 & 85 & 241 \\
\hline Striatura exigua & 27 & 21 & 45 & 48 & 141 & 28 & 38 & 45 & 17 & 128 \\
\hline Gastrocopta tappaniana & 11 & 12 & 34 & 19 & 76 & 32 & 110 & 76 & 37 & 255 \\
\hline Vertigo modesta & 15 & 18 & 23 & 9 & 65 & 8 & 23 & 30 & 31 & 92 \\
\hline Carychium exile canadense & 2 & 10 & 13 & 34 & 59 & 23 & 5 & 51 & 15 & 94 \\
\hline Punctum minutissimum & 2 & 2 & 4 & 21 & 29 & 6 & 2 & 5 & 9 & 22 \\
\hline Pupisoma minus ${ }^{l}$ & 2 & 0 & 1 & 8 & $11=$ & 0 & 0 & 0 & 0 & 0 \\
\hline Total & 7854 & 5660 & 9349 & 4533 & 27396 & 4970 & 4936 & 7056 & 3237 & 20199 \\
\hline
\end{tabular}

${ }^{1}$ Tentative identification by the Royal Ontario Museum, Toronto.

of a Type-I error was set at $P<0.05$. To determine if gastropod densities varied among treatments a repeated measures analysis of variance was performed (Meredith and Stehman 1991; Norusis 1992a; Gumpertz and Brownie 1993) followed by Tukey's HSD test (Zar 1984). Tests for differences in densities among the four sampling periods through the summer and any treatment $\times$ time interactions were also done using this procedure. Data were first normalized using a logarithmic transformation $\left(\log _{10}\right)$. Population densities in the uncut forest and in the control area of block three were compared using a Wilcoxon Rank Sum test (Bradley 1968; Norusis 1992b).

\section{Results}

\section{Gastropod Response}

Totals of 27,396 and 20,199 terrestrial gastropods were collected from the four experimental blocks, over the four sample periods, in the summers of 1993 and 1994, respectively (Table 1). Twenty-one species, including 19 snails and two slugs (Deroceras laeve and Pallifera dorsalis), were collected from each block in each of the two years, with the exception of the snail, Pupisoma minus, which was absent on block two in 1993 and was not found on any block in 1994.

The total number of terrestrial gastropods collected varied among blocks within each of the two years (Table 1). Block three had the greatest abundance of snails and slugs in 1993 and 1994, while block four had the lowest in each year. Total numbers of gastropods collected also varied between years for each block, with greater numbers collected in 1993 than in 1994 (Table 1).

Mean overall gastropod density, and the individual densities of the 11 most common species, did not vary between treatments within blocks either before (1993) or after treatments were applied (1994) (Fig. 1; Table 2). In 1993, mean gastropod density and the densities of six species (Euconulus fulvus,
Strobilops labyrinthica, Vertigo gouldi, Striatura milium, Columella edentula, and Anguispira alternata) increased over the four sample periods during the summer (Table 2). In 1994 , only S. milium increased in density during the summer (Table 2). No treatment $\times$ time interaction effects were evident in either the mean overall gastropod density or any of the 11 most common species of gastropod during the summers of 1993 and 1994 (Table 2).

\section{Regenerating Plantation vs. Uncut Forest}

Species richness of gastropods in the regenerating and uncut forests were similar ( 20 spp. vs. 18 spp., respectively) (Table 3 ). Overall, mean ( \pm SE) gastropod density was higher in the regenerating forest $\left(15.5 \pm 1.3 \mathrm{~m}^{-2}\right)$ than in the uncut forest $\left(9.4 \pm 0.6 \mathrm{~m}^{-2}\right)(P=0.008)$. This difference was due primarily to greater numbers of Zonitoides arboreus $(P$ $=0.014)$, E. fulvus $(P=0.01), D$. laeve $(P<0.0001), V$. gouldi $(P=0.002)$, and $S$. milium $(P=0.041)$ in the regenerating forest. Discus cronkhitei was most dense in the uncut forest $(P<0.0001)$; Vertigo modesta and Punctum minutissimum were absent from the uncut forest.

\section{Climatic Conditions}

Mean daily air temperatures were similar in 1993 and 1994 (Fig. 2A). However, spring and summer rainfall was greater in 1993 than in 1994 (Fig. 2B).

\section{Discussion}

All 21 species of terrestrial gastropod identified on the four experimental blocks were indigenous to North America (Pilsbry 1939-1948; Chichester and Getz 1969) and have previously been documented in northwestern Ontario (Oughton 1948); but, a greater number of species is reported here than in previous studies of similar northern habitats. Kearney and 

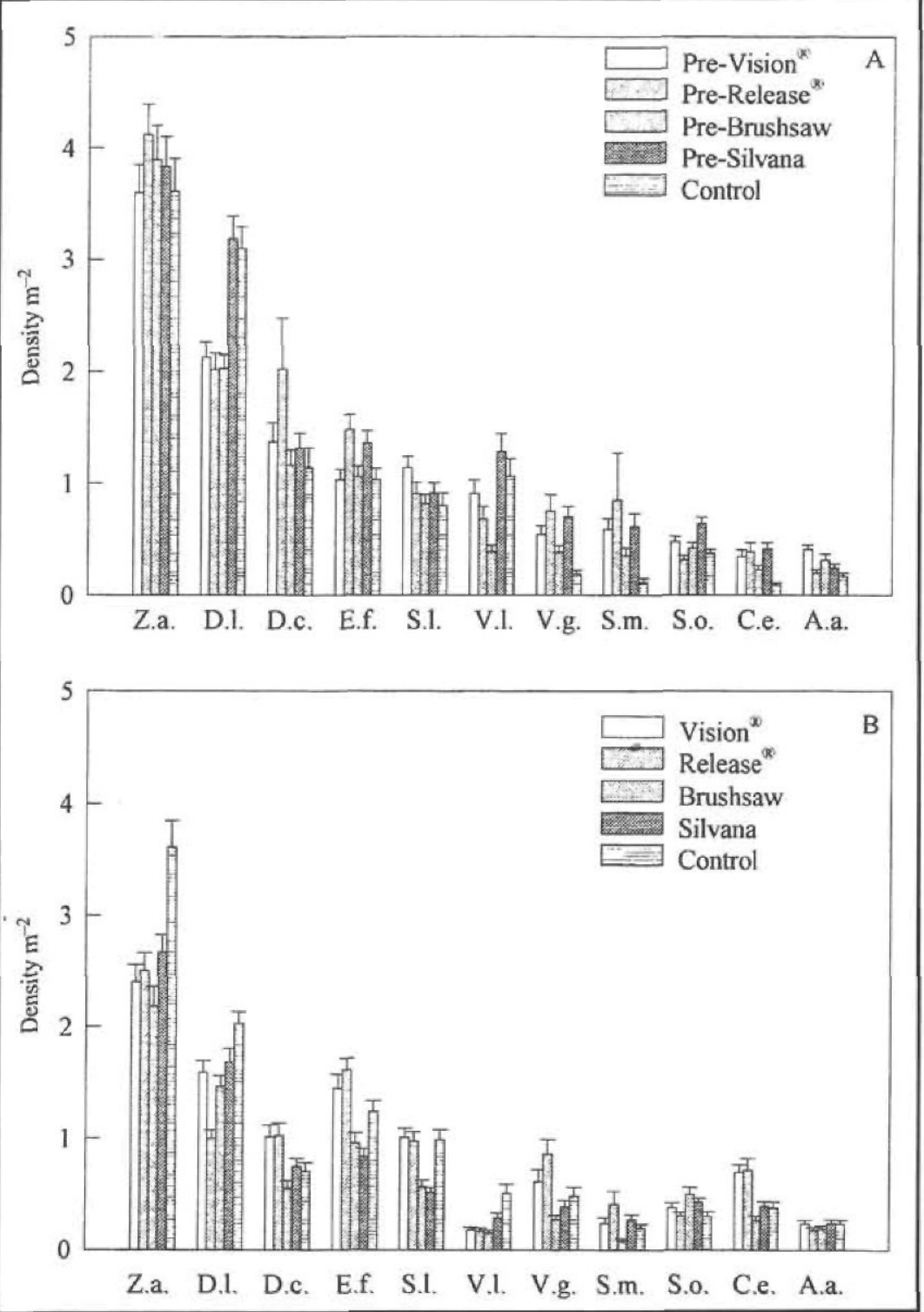

Fig. 1. Mean densities ( $\pm S E$ ) of each of the 11 most common species of terrestrial gastropod in the four conifer release treatment areas and the control area in 1993 (A) and 1994 (B). [Z.a. = Zonitoides arboreus $;$ D.1. $=$ Deroceras laeve $;$ D.c. $=$ Discus cronkhitei; E.f. = Euconulus fulvus; S.1. = Strobilops labyrinthica; V.l. = Vitrina limpida; V.g. = Vertigo gouldi; S.m. = Striatura milium; S.o. = Succinea ovalis; C.e. $=$ Columella edentula; A.a. $=$ Anguispira alternata].
Gilbert (1978) identified 16 species of terrestrial gastropod, including two introduced species of slug, from the Himsworth Game Preserve south of North Bay, Ontario. Van Es and Boag (1981), Kralka (1986), and Locasciulli and Boag (1987) collected 18,13, and 11 species of gastropod, respectively, from a variety of coniferous, deciduous, and mixedwood stands in the boreal forest region of Alberta (Rowe 1972). In addition, Boag and Wishart (1982) identified a total of 15 species from nine different habitat types in southwestern Alberta. The greater number of gastropod species collected in the current study may be a result of more abundant near-ground vegetation typical of early, rather than late, stages of forest succession (Gratowski 1967; Kimmins 1987). Live vegetation is not considered essential as a source of food for snails and slugs. Rather, they are believed to feed on decomposing organic material, soil algae, and fungal hyphae (Boycott 1934; Chatfield 1974). Vegetation is, however, important in providing the nearground temperature and moisture conditions favoured by gastropods (Hunter 1964).
Total mean density of surface active gastropods was $12 \mathrm{~m}^{-2}$ and ranged from $6 \mathrm{~m}^{-2}$ to $18 \mathrm{~m}^{-2}$ on the experimental blocks. Using sampling techniques similar to those used in this study, Lankester and Peterson (1996) found gastropod densities of $2 \mathrm{~m}^{-2}$ and $4 \mathrm{~m}^{-2}$ in two different habitats in northeastern Minnesota. As well, Boag and Wishart (1982) and Kearney and Gilbert (1978) reported total numbers of terrestrial gastropods from which mean densities on the surface of the forest floor were calculated to be $2 \mathrm{~m}^{-2}$ and $38 \mathrm{~m}^{-2}$, respectively. However, Kralka (1986) examined $5 \mathrm{~cm}$ deep soil cores and estimated a total mean density of $80 \mathrm{~m}^{-2}$, with maximum densities of Discus cronkhitei and Vertigo gouldi reaching $340 \mathrm{~m}^{-2}$ and $460 \mathrm{~m}^{-2}$, respectively, suggesting that large numbers of gastropods inhabit the superficial soil layer. Hawkins et al. (1997) compared the cardboard sheet and soil core sampling methods and estimated the density of surface active gastropods was $28 \mathrm{~m}^{-2}$ using cardboard sheets while a mean density of 1607 $\mathrm{m}^{-2}$ of the same gastropod species was estimated to be in the $10 \mathrm{~cm}$ depth of soil beneath the sheets. Clearly, many more 
Table 2. $F$-statistics and $P$-values of main treatment and interaction effects, calculated from repeated measures ANOVA, for the total number of gastropods and each of the 11 most common terrestrial gastropod species in 1993 (pre-treatment) and 1994 (post-treatment)

1993 (pre-treatment)

\begin{tabular}{|c|c|c|c|c|c|c|}
\hline & & & & & & \\
\hline & Treatment & Time & Treatment xtime & Treatment & Time & Treatment xtime \\
\hline Total & $F^{1}=0.52, P>0.05$ & $F^{2}=6.52, P<0.05^{*}$ & $F^{3}=1.64, P>0.05$ & $F=1.16, P>0.05$ & $F=0.26, P>0.05$ & $F=0.71, P>0.05$ \\
\hline Zonitoides arboreus & $F=0.46, P>0.05$ & $F=3.21, P>0.05$ & $F=0.44, P>0.05$ & $F=0.87, P>0.05$ & $F=2.32, P>0.05$ & $F=0.69, P>0.05$ \\
\hline Deroceras laeve & $F=1.35, P>0.05$ & $F=2.38, P>0.05$ & $F=1.54, P>0.05$ & $F=2.43, P>0.05$ & $F=2.03, P>0.05$ & $F=0.67, P>0.05$ \\
\hline Euconulus fulvus & $F=0.76, P>0.05$ & $F=7.72, P<0.05^{*}$ & $F=1.33, P>0.05$ & $F=1.92, P>0.05$ & $F=0.19, P>0.05$ & $F=1.18, P>0.05$ \\
\hline Strobilops labyrinthica & $F=0.29, P>0.05$ & $F=11.67, P<0.05^{*}$ & $F=1.08, P>0.05$ & $F=0.79, P>0.05$ & $F=1.77, P>0.05$ & $F=0.67, P>0.05$ \\
\hline Vitrina limpida & $F=1.02, P>0.05$ & $F=1.04, P>0.05$ & $F=1.00, P>0.05$ & $F=1.00, P>0.05$ & $F=0.34, P>0.05$ & $F=1.00, P>0.05$ \\
\hline Vertigo gouldi & $F=1.29, P>0.05$ & $F=36.93, P<0.05^{*}$ & $F=1.46, P>0.05$ & $F=1.77, P>0.05$ & $F=1.68, P>0.05$ & $F=0.80, P>0.05$ \\
\hline Columella edentula & $F=1.46, P>0.05$ & $F=58.75, P<0.05^{*}$ & $F=2.00, P>0.05$ & $F=2.11, P>0.05$ & $F=3.09, P>0.05$ & $F=1.29, P>0.05$ \\
\hline Anguispira alternata & $F=0.94, P>0.05$ & $F=4.08, P<0.05^{*}$ & $F=1.33, P>0.05$ & $F=0.20, P>0.05$ & $F=3.00, P>0.05$ & $F=1.00, P>0.05$ \\
\hline
\end{tabular}

*Significant at $P<0.05$

${ }^{1} F$ distribution with 4 and 12 degrees of freedom.

${ }^{2} F$ distribution with 3 and 9 degrees of freedom.

${ }^{3} \mathrm{~F}$ distribution with 12 and 36 degrees of freedom.

Table 3. Mean densities ( \pm SE) of terrestrial gastropods in the regenerating plantation and the uncut forest

\begin{tabular}{lccc}
\hline & Regenerating plantation & Uncut forest & $P_{\text {-value }}{ }^{1}$ \\
\hline Zonitoides arboreus & $4.14 \pm 0.44$ & $2.28 \pm 0.21$ & $P=0.014$ \\
Euconulus fulvus & $2.17 \pm 0.23$ & $1.17 \pm 0.12$ & $P=0.010$ \\
Strobilops labyrinthica & $1.79 \pm 0.24$ & $1.36 \pm 0.16$ & $P=0.489$ \\
Deroceras laeve & $2.20 \pm 0.20$ & $0.72 \pm 0.09$ & $P<0.001$ \\
Vitrina limpida & $1.14 \pm 0.24$ & $0.65 \pm 0.10$ & $P=0.257$ \\
Discus cronkhitei & $0.41 \pm 0.08$ & $1.28 \pm 0.15$ & $P<0.001$ \\
Cochlicopa lubrica & $0.49 \pm 0.12$ & $0.51 \pm 0.08$ & $P=0.059$ \\
Vertigo gouldi & $0.77 \pm 0.16$ & $0.16 \pm 0.05$ & $P=0.002$ \\
Columella edentula & $0.49 \pm 0.09$ & $0.34 \pm 0.07$ & $P=0.276$ \\
Succinea ovata & $0.47 \pm 0.10$ & $0.23 \pm 0.05$ & $P=0.143$ \\
Anguispira alternata & $0.19 \pm 0.05$ & $0.28 \pm 0.07$ & $P=0.315$ \\
Striatura milium & $0.34 \pm 0.09$ & $0.10 \pm 0.03$ & $P=0.041$ \\
Striatura exigua & $0.23 \pm 0.05$ & $0.09 \pm 0.03$ & $P=0.027$ \\
Gastrocopta tappaniana & $0.19 \pm 0.09$ & $0.04 \pm 0.02$ & $P=0.063$ \\
Vertigo ovata & $0.09 \pm 0.03$ & $0.06 \pm 0.04$ & $P=0.082$ \\
Zöogenetes harpa & $0.05 \pm 0.02$ & $0.09 \pm 0.03$ & $P=0.570$ \\
Pallifera dorsalis & $0.07 \pm 0.03$ & $0.05 \pm 0.02$ & $P=0.990$ \\
Vertigo modesta & $0.12 \pm 0.04$ & 0 & $P=0.002$ \\
Carychium exile canadense & $0.09 \pm 0.05$ & $0.01 \pm 0.01$ & $P=0.056$ \\
Punctum minutissimum & $0.02 \pm 0.02$ & 0.157 & $P=0.008$ \\
Total & $15.48 \pm 1.31$ & $9.43 \pm 0.57$ & \\
P-values based & & & \\
\hline
\end{tabular}

${ }^{1} P$-values based on a Wilcoxon Rank Sum Test.

gastropods are present within the litter and underlying soil than are active on the surface. Although cardboard sheets provide a time-efficient method of sampling, numbers collected beneath them are likely to be influenced by surface microclimatic factors important for gastropod mobility (Hawkins et al. 1997).

Mean gastropod density increased to a maximum of $21 \mathrm{~m}^{-2}$ over the summer of 1993, corresponding to a total of 27, 396 gastropods collected, but density remained fairly stable throughout the summer of 1994 , at about $10 \mathrm{~m}^{-2}$, with only 20,199 collected. This difference between years was not related to the conifer release treatments since gastropod densities on both treated and control areas were lower in 1994. Rather, the greater amount of spring and summer precipitation in 1993 probably increased soil moisture on the blocks and may have improved the reproductive success of gastropods (Walton 1963; Berry 1966) causing populations to grow over the summer. In addition, periods of rain and increased soil moisture in 1993 may have caused gastropods to move toward the surface (Locascuilli and Boag 1987) where they were more likely to be sampled beneath cardboard sheets.

Differences among the four experimental blocks may have been related to soil moisture. Blocks one and three had the greatest densities of snails and slugs in both years of the study. These blocks had poor drainage and greater soil moisture than blocks two and four (Reynolds et al. 1997). Positive correlations between soil moisture and the distribution of both snails and slugs have previously been demonstrated (Prior 1985).

Despite marked changes in vegetation structure on the conifer released sites (Bell et al. 1997a), no differences were evident in species richness and density of gastropods following treatments. Removal of vegetation from an area may cause nearground temperatures to be more extreme and relative humidity to decrease (Geiger 1957; Coates et al. 1991; McInnis and 

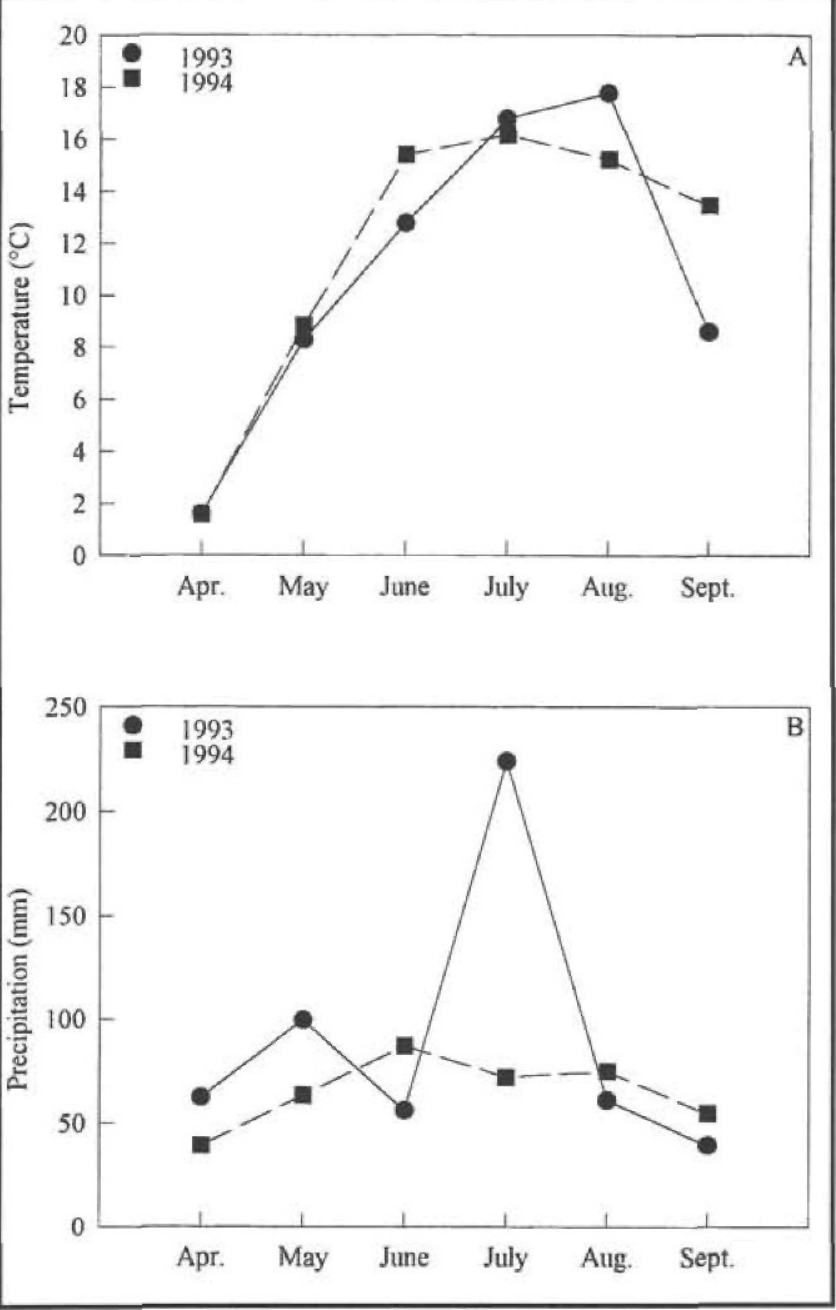

Fig. 2. Mean daily air temperatures (A) and total monthly precipitation (B) in 1993 and 1994.

Roberts 1995). Terrestrial gastropods may respond to such conditions by moving deeper into the soil. However, once nearground vegetation has regenerated and if soil temperature and moisture conditions are restored, resident snails and slugs may again become abundant at or near the surface. Although tree and shrub cover was reduced following treatments in this study, the abundance of near-ground vegetation remained the same or increased the following year (Bell et al. 1997a). Near-ground temperature was similar on the treatment areas in 1994 and although relative humidity was lower on conifer released areas, it remained between 80 and $90 \%$ (Reynolds et al. 1997). Therefore, microenvironmental conditions experienced by snails and slugs changed little and continued to provide favourable habitat. Maze and Johnstone (1986) observed the greatest number of gastropod species and highest densities of snails and slugs in areas with dense near-ground vegetation. They attributed this to the shelter and protection provided by the abundant herbaceous vegetation. As well, Andersen and Halvorsen (1984) found the greatest numbers of two particular species, Cochlicopa lubrica and Vertigo modesta, in areas rich with ground vegetation.

Strayer et al. (1986) studied the effects of three types of forest disturbance (agricultural cropping, burning, and clearcut- ting) on terrestrial gastropods and concluded that any relationship between disturbance and short-term changes in gastropod numbers was unclear. Species richness and density appeared to decline following disturbance, but declines seemed shortlived; sites disturbed five years earlier had already returned to pre-disturbance levels. They also suggested that disturbed sites were recolonized as a result of gastropods moving in from surrounding, undisturbed habitat. However, rapid dispersal into large disturbed areas seems doubtful since terrestrial gastropods are assumed to be relatively immobile. Considering findings reported here, and by Kralka (1986) and Hawkins et al. (1997), a more likely explanation is that the large reservoir of gastropods in the soil is the source of colonizers and vertical movement may quickly restore the detectable community on the surface, provided that suitable microclimate is reestablished for all of the original species.

The density of surface active terrestrial gastropods was greater on the regenerating control area of block three $\left(15.5 \pm 1.3 \mathrm{~m}^{-2}\right)$ than in the adjacent uncut forest $\left(9.4 \pm 0.6 \mathrm{~m}^{-2}\right)$. Beach (1992) similarly found greater numbers of gastropods on 510 year old regenerating clearcuts than in uncut forests. In our study, the regenerating area was characterized by a greater variety of deciduous species and an abundance of herbaceous ground vegetation. The uncut forest, on the other hand, had a closed canopy dominated by white spruce and trembling aspen. The understory was sparse and the litter had a noticeably greater coniferous component.

Gastropod densities typically are greater in deciduous rather than coniferous forests (Boycott 1934; Karlin 1961). For example, Boag and Wishart (1982) observed gastropod densities of $3.2 \mathrm{~m}^{-2}$ and $0.5 \mathrm{~m}^{-2}$ in mature deciduous and coniferous forests, respectively. Similarly, Gleich and Gilbert (1976) reported gastropod densities of $5 \mathrm{~m}^{-2}$ in a deciduous forest and $3 \mathrm{~m}^{-2}$ in a coniferous forest in central Maine. This difference has generally been attributed to the relative contributions of deciduous and coniferous species to the litter and resulting chemical differences in the underlying soil. However, Locasciulli and Boag (1987) found a strong positive correlation between gastropod abundance and the amount of litter, regardless of its composition.

Species richness was somewhat greater on the regenerating control area than in the uncut forest; $V$. modesta and Punctum minutissimum were not collected in the latter. Kralka (1986) also reported more gastropod species in deciduous forests (13 species) than in coniferous dominated stands (eight species). However, Locasciulli and Boag (1987) found the same nine species of gastropod in both a deciduous and a coniferous forest.

The regenerating plantations appeared more favourable to snails and slugs than the uncut forest. Being in an early successional stage and having a greater variety and abundance of near-ground vegetation and deciduous litter, they may provide a wider range of suitable microsites for snails and slugs. Although light intensity and near-ground temperatures are greater on conifer plantations than in uncut forests (Margolis and Brand 1990; Spittlehouse and Stathers 1990), soil moisture remains high because of less transpiring vegetation (Kochenderfer and Wendel 1983). Relative humidity at ground level beneath a dense layer of herbaceous vegetation can approach $100 \%$, while the relative humidity immediately above it may be only $50 \%$ (Geiger 1957; Oke 1978; Begon et al. 1990). As well, pH values and 
available $\mathrm{Ca}^{2+}$ are higher in soils overlain by deciduous leaf litter (Burch 1955; Millar 1974; Swift et al. 1979), and the distribution of snails and slugs has been correlated with these conditions (Cameron 1973; Waldén 1981; Gärdenfors 1992). Gastropods require abundant sources of available calcium for shell precipitation and egg development during growth and reproduction (Wilbur 1964; Fournié and Chétail 1984).

The objective of conifer release is to suppress competing vegetation, allowing young conifers to become established and promoting more rapid succession of a conifer dominated stand (Walstad and Kuch 1987; Freedman et al. 1993). Because much of the literature suggests that gastropods prefer forests with a strong deciduous component, tended conifer plantations would be expected, eventually, to become less suitable for them. However, over the short and medium term, habitat alteration appears to have the opposite effect. Results reported here suggest that within five to eight years of a disturbance such as logging, regenerating areas can be expected to have markedly greater density and somewhat greater richness of gastropod species than occurred in the original mature forests that they replace. Increased richness is possibly due to previously rare species becoming numerous enough, as the area regenerates, to be detected by the cardboard sheet method. In the short term, immediately following management of competing vegetation on a regenerating plantation, no changes in gastropod populations could be detected among the alternatives examined, at least within one year of chemical, mechanical and motor-manual release treatments.

\section{Acknowledgements}

We gratefully acknowledge funding provided for this work by the Vegetation Management Alternatives Program (VMAP), through the Agricultural Research Institute of Ontario (ARIO), under the Sustainable Forestry Initiative, Ontario Ministry of Natural Resources, Sault Ste. Marie, Ontario. We thank Andrew Nelson, Jackie Hrabok and Cam Oomen for assisting with gastropod collection, Karen Watt for helping with the preparation of the manuscript and John Winters, Heather Barns and Nikki Wood for help on-site.

\section{References}

Andersen, J. and O. Halvorsen. 1984. Species composition, abundance, habitat requirements and regional distribution of terrestrial gastropods in Arctic Norway. Polar Biol. 3: 45-53.

Baker, F.C. 1942. Land and freshwater mollusca of New Hampshire. Am. Midl. Nat. 27: 74-85.

Beach, T.D. 1992. Transmission of meningeal worm: an analysis of sympatric use of habitat by white-tailed deer, moose and gastropods. M.Sc. thesis, University of New Brunswick, Fredericton, New Brunswick. 56 p.

Begon, M., J.L. Harper and C.R. Townsend. 1990. Ecologyindividuals, populations and communities. Blackwell Scientific Publications. Boston, Massachusetts. 945 p.

Bell, F.W., R.A. Lautenschlager, R.G. Wagner, D.G. Pitt, J.W. Hawkins and K.R. Ride. 1997a. Motor-manual, mechanical, and herbicide release affect early successional vegetation in northwestern Ontario. For. Chron. 73: 61-68.

Bell, F.W., K.R. Ride, M.L. St.-Amour and M. Ryans. 1997b. Productivity, cost efficacy, and cost effectiveness of motor-manual, mechanical and herbicide release of boreal spruce plantations. For. Chron. 73: 39-46.

Berry, A.J. 1966. Population structure and fluctuations in the snail fauna of a Malayan limestone hill. J. Zool. 150: 11-27.

Beyer, W.N. and D.M. Saari. 1977. Effect of tree species on the dis- tribution of slugs. J. Anim. Ecol. 46: 697-702.

Boag, D.A. and W.D. Wishart. 1982. Distribution and abundance of terrestrial gastropods on a winter range of bighorn sheep in southwestern Alberta. Can. J. Zool. 60: 2633-2640.

Boycott, A.E. 1934. The habits of land Mollusca in Britain. J. Ecol. 22: $1-38$,

Bradley, J.V. 1968. Distribution-free statistical tests. PrenticeHall, Englewood Cliffs, New Jersey. 388 p.

Brandmayr, P. and T.Z. Brandmayr. 1986. Food and feeding behaviour of some Licinus species (Coleoptera Carabidae Licinini). Monitore Zool. Ital. 20: 171-181.

Burch, J.B. 1955. Some ecological factors of the soil affecting the distribution and abundance of land snails in eastern Virginia. Nautilus 69(2): 62-69.

Burch, J.B. 1956. Distribution of land snails in plant associations in eastern Virginia. Nautilus 70(2): 60-64.

Burch, J.B. 1962. How to know the eastern land snails. William C. Brown Co., Dubuque, Iowa. 214 p.

Buse, L.J., R.G. Wagner and B. Perrin. 1995. Public attitudes towards forest herbicide use and the implications for public involvement. For. Chron. 71(5): 596-600.

Cameron, R.A.D. 1973. Some woodland mollusc faunas from southern England. Malacologia 14: 355-370.

Cameron, R.A.D., K. Down and D.J. Pannett. 1980. Historical and environmental influences on hedgerow snail faunas. Biol. J. Linn. Soc. 13: 75-87.

Campbell, R.A. 1984. The value of herbicides in forest management. Can. For. Indust. 104(31): 41-44.

Campbell, R.A. 1990. Herbicide use for forest management in Canada: where we are and where we are going. For. Chron. 66(4): 355-360.

Campbell, R.A. 1991. Silvicultural herbicides in Canada: registration status and research trends. For. Chron. 67(5): 520-527.

Chatfield, J.E. 1974. A summary of studies on food and feeding in some European land snails. Malacol. Rev. 8: 123-125.

Chichester, L.F. and L.L. Getz. 1969. The ecology and zoogeography of Arionid and Limacid slugs introduced into northeastern North America. Malacologia 7(2-3): 313-346.

Churchfield, S. 1984. Dietary separation in three species of shrew inhabiting water-cress beds. J. Zool. 204: 211-228.

Coates, K.D., W.H. Emmingham and S.R. Radosevich. 1991. Coniferseedling success and microclimate at different levels of herb and shrub cover in a Rhododendron-Vaccinium-Menziesia community of south central British Columbia. Can J. For. Res. 21: 858-866.

Digweed, S.C. 1993. Selection of terrestrial gastropod prey by Cychrine and Pterostichine ground beetles (Coleoptera: Carabidae). Can. Entomol. 125: 463-472.

Environics Research Group. 1992. National survey of Canadian public opinion on forestry issues, 1991. Highlights from a survey commissioned by Forestry Canada. For. Planning Can. 8(3): 25-26.

Fournié, J. and M. Chétail. 1984. Calcium dynamics in land gastropods. Amer. Zool. 24: 857-870.

Freedman, B. 1991. Controversy over the use of herbicides in forestry, with particular reference to glyphosate usage. J. Environ. Sci. Health C8: 277-286.

Freedman, B., R. Morash and D. MacKinnon. 1993. Short-term changes in vegetation after the silvicultural spraying of glyphosate herbicide onto regenerating clearcuts in Nova Scotia, Canada. Can. J. For. Res. 23: 2300-2311.

Gärdenfors, U. 1992. Effects of artificial liming on land snail populations. J. Appl. Ecol. 29: 50-54.

Geiger, R. 1957. The climate near the ground. Das klima der bodennahen. [Translated from 2nd German ed. by M.N. Stewart et al.] Harvard University Press, Cambridge, Massachusetts. 494 p.

Gleich, J.G. and F.F. Gilbert. 1976. A survey of terrestrial gastropods from central Maine. Can. J. Zool. 54: 620-627.

Gleich, J.G., F.F. Gilbert and N.P. Kutscha. 1977. Nematodes in terrestrial gastropods from central Maine. J. Wildl. Dis. 13: 43-46. Gratowski, H. 1967. Ecological considerations in brush control. pp. 
124-140. In: Herbicide and vegetation management in forest, range, and noncrop lands. Oregon State University, Corvallis, Oregon.

Gumpertz, M.L. and C. Brownie. 1993. Repeated measures in randomized block and split-plot experiments. Can. J. For. Res. 23: $625-639$.

Hamilton, W.J. 1941. The food of small forest mammals in eastern United States. J. Mamm. 22: 250-263.

Hawkins, J.W., M.W. Lankester and R.R.A. Nelson. 1996. Sampling terrestrial gastropods using cardboard sheets. Malacologia 39(1): in press.

Hunter, R.W. 1964. Physiological aspects of ecology in nonmarine mollusca. pp. 83-126 In: K.M. Wilbur and C.M. Young, eds. Physiology of Mollusca. Academic Press, New York.

Karlin, E.J. 1961. Ecological relationships between vegetation and the distribution of land snails in Montana, Colorado and New Mexico. Am. Midl. Nat. 65(1): 60-66.

Kearney, S.R. and F.F. Gilbert. 1978. Terrestrial gastropods from the Himsworth Game Preserve, Ontario, and their significance in Parelaphostrongylus tenuis transmission. Can. J. Zool. 56: 688-694. Kimmins, J.P. 1987. Forest ecology. Macmillian Publishing Company, New York. 531 p.

Kochenderfer, J.N. and G.W. Wendel. 1983. Plant succession and hydrologic recovery on a deforested and herbicided watershed. For. Sci. 29: 545-558.

Kralka, R.A. 1986. Population characteristics of terrestrial gastropods in boreal forest habitats. Am. Midl. Nat. 115(1): 156-164.

Lankester, M.W. and R.C. Anderson. 1968. Gastropods as intermediate hosts of Pneumostrongylus tenuis Dougherty of whitetailed deer. Can. J. Zool. 46: 373-383.

Lankester, M.W. and W.J. Peterson. 1996. The possible importance of wintering yards in the transmission of Parelaphostrongylus tenuis to white-tailed deer and moose. J. Wildl. Dis. 32(1): 31-38. Lautenschlager, R.A. 1993. Response of wildlife to forest herbicide applications in northern coniferous ecosystems. Can. J. For. Res. 23: 2286-2299.

Lautenschlager, R.A., F.W. Bell, R.G. Wagner and J.A. Winters. 1997. The Fallinfsnow Ecosystem Project: Comparing conifer release alternatives in northwestern Ontario. For. Chron. 73: 35-38. Locasciulli, O. and D.A. Boag. 1987. Microdistibution of terrestrial snails (Stylommatophora) in forest litter. Can. Field-Nat. 101(1): 76-81. Margolis, H.A. and D.G. Brand. 1990. An ecophysiological basis for understanding plantation establishment. Can. J. For. Res. 20: 375-390. Mason, C.F. 1970. Snail populations, beech litter production, and the role of snails in litter decomposition. Oecologia 5: 215-239.

Maze, R.J. and C. Johnstone. 1986. Gastropod intermediate hosts of the meningeal worm Parelaphostrongylus tenuis in Pennsylvania: observations on their ecology. Can. J. Zool. 64: 185-188.

MeInnis, B.G. and M.R. Roberts. 1995. Seedling microenvironment in full-tree and tree-length logging slash. Can. J. For. Res. 25: 128-136.

Meredith, M.P. and S.V. Stehman. 1991. Repeated measures experiments in forestry: focus on analysis of response curves. Can. J. For. Res. 21: 957-965.

Millar, C.S. 1974. Decomposition of coniferous leaf litter. pp. 105128. In C.H. Dickinson and G.J.H. Pugh, eds. Biology of plant litter decomposition. Academic Press, New York.

Newell, P.F. 1971. Mollusca. pp. 128-149. In J. Phillipson, ed. Methods of study in quantitative soil ecology: population, production and energy flow. Blackwell Scientific Publications, Oxford, England. Norusis, M.J. 1992a. SPSS/PC+ Advanced Statistics Version 5.0. SPSS Inc., Chicago, Illinois. 481 p.

Norusis, M.J. 1992b. SPSS/PC+ Base System User's Guide Version 5.0. SPSS Inc., Chicago, Illinois. p. 910.

Oke, T.R. 1978. Boundary layer climates. Methuen and Co. Ltd., London. 372 p.

Oughton, J. 1948. A zoogeographical study of the land snails of Ontario. University of Toronto, Biological Series No. 57.126 p.

Pilsbry, H.A. 1939-1948. Land mollusca of North America (North of Mexico). Acad. Nat. Sci. Philadelphia Monogr. No. 3. Vols. 1 and 2.
Prior, D.J. 1985. Water-regulatory behaviour in terrestrial gastropods. Biol. Res. 60: 403-424.

Radosevich, S.R. and K. Osteryoung. 1987. Principals governing plant-environment interactions. pp. 105-156. In: J.D. Walstad and P.J. Kuch, eds. Forest vegetation management for conifer production. John Wiley and Sons Inc., New York.

Raskevitz, R.F., A.A. Kocan and J.H. Shaw. 1991. Gastropod availability and habitat utilization by wapiti and white-tailed deer sympatric on range enzootic for meningeal worm. J. Wildl. Dis. 27(1): 92-101.

Reinink, K. 1979. Observations on the distribution of land snails in the woods of the Ijsselmeer polders. Basteria 43: 33-45.

Reynolds, P.E., J.A. Simpson, R.A. Lautenschlager, F.W. Bell, A.M. Gordon, D.A. Buckley and D.A. Gresch. 1997. Alternative conifer release treatments affect below- and near-ground microclimate. For. Chron. 73: 75-82.

Richter, K.O. 1979. Aspects of nutrient cycling by Ariolimax columbianus (Mollusca: Arionidae) in Pacific Northwest coniferous forests. Pedobiologia 19: 60-74.

Rowe, J.S. 1972. Forest regions of Canada. Publication No. 1300 , Department of the Environment, Canadian Forestry Service, Ottawa, Ontario. 172 p.

Rowley, M.A., E.S. Loker, J.F. Pagels and R.J. Montali. 1987. Terrestrial gastropod hosts of Parelaphostrongylus tenuis at the National Zoological Park's Conservation and Research Center, Virginia. J. Parasit. 73(6): 1084-1089.

Rudge, M.R. 1968. The food of the common shrew Sorex araneus L. (Insectivora: Soricidae) in Britain. J. Anim. Ecol. 37: 565-581. South, A. 1980. A technique for the assessment of predation by birds and mammals on the slug Deroceras reticulatum (Muller) (Pulmonata: Limacidae). J. Conchol. 30: 229-234.

Spittlehouse, D.L. and R.J. Stathers. 1990. Seedling microclimate. British Columbia Ministry of Forests, Victoria, British Columbia. Land Manage. Rep. No. 65. p. 28.

Strayer, D., D.H. Pletscher, S.P. Hamburg and S.C. Nodvin. 1986. The effects of forest disturbance on land gastropod communities in northern New England. Can. J. Zool. 64: 2094-2098.

Sutton, R.F. 1969. Chemical control of competition in plantations. For. Chron. 45(4): 252-256.

Swift, M.J., O.W. Heal and J.M. Anderson. 1979. Decomposition in terrestrial ecosystems. University of California Press, Berkeley, California. 372 p.

Thompson, D.G., D.G. Pitt, B. Staznik, N.J. Payne, D. Jaipersaid, R.A. Lautenschlager and F.W. Bell. 1997. On-target deposit and vertical distribution of aerially released herbicides. For. Chron. 73: 47-59.

Van Es, J. and D.A. Boag. 1981. Terrestrial molluscs of central Alberta. Can. Field-Nat. 95(1): 75-79.

Wagner, R.G. 1993. Research directions to advance forest vegetation management in North America. Can. J. For. Res. 23: 2317-2327. Waldén, H.W. 1981. Communities and diversity of land molluscs in Scandinavian woodlands. I. High diversity communities in taluses and boulder slopes in SW Sweden. J. Conch. 30: 351-372.

Walstad, J.D. and P.J. Kuch. 1987. Forest vegetation management for conifer production. John Wiley and Sons Inc., New York. 523 p. Walton, M.L. 1963. Length of life in west American land snails. Nautilus 76(4): 127-131.

Whitaker, J.O. 1966. Food of Mus musculus, Peromyscu maniculatus bairdi and Peromyscus leucopus in Vigo County, Indiana. J. Mamm. 47(3): 473-486.

Whitaker, J.O. and R.E. Mumford. 1972. Food and ectoparasites of Indiana shrews. J. Mamm. 53(2): 329-335.

Wilbur, K.M. 1964. Shell formation and regeneration. pp. 243-282. In: K.M. Wilbur and C.M. Young, eds. Physiology of Mollusca. Academic Press, New York.

Zar, J.H. 1984. Biostatistical analysis. Prentice Hall, Englewood Cliffs, New Jersey. 718 p. 